\title{
THE CITY AS SOCIAL SCULPTURE
}

\section{A B S T R A C T}

The arguments in this paper try to show that the city is basically a social space and that before its fixed physical matter in the form of architecture and urban structures, it is the people that construct the essential character and presence of a city. The idea of social sculpture is taken as a vivid metaphor that refers back to the work and ideas of Joseph Beuys. Beuys claimed that events and actions of the people in a city were social sculptures and he illustrated this in his famous street-sweeping performance with his students. The city belongs to the people and cities are responsibilities of their inhabitants. In arguing for this, the paper refers also to the GEZI events in Istanbul. These arguments lead to the conclusion that more vital and meaningful art of the future will have to relate to the urban context more than anything else. 


\section{INTRODUCTION}

My argument focuses on the idea that the city is constituted primarily by the activities, relationships, bodies and attitudes of its social entities. I will back-up this thesis with Beuys' term 'social sculpture' which he coined for a social-activist event that he realized with his students, sweeping the streets and collecting trash. The term social sculpture is indicative of a relationship between the larger public as society and art which has a specific physicality, place and meaning. 'Social sculpture' has to be understood as being very different from 'public sculpture'; it refers to a community of individuals that create a formal mass which is both material and metaphysical.

I use the term coined by Beuys for a specific event, for a more comprehensive context, the city. The city understood as social sculpture implies a greater web of relationships that are physical, spiritual, political and aesthetic.

I argue that recent uprisings and activist events which have been taking place in many cities, voicing new expectations from the city, have given form to a new concept of urban life.

\section{SOCIAL SCULPTURE}

Beuys referred to his action of sweeping the streets with his students, on the Workers Day on May 1, as 'Social Sculpture'. This concept which is a synthesis of art and politics, introduced in the early 1960's, was prophetic of the dynamics and awareness created by urban manifestations and social uprisings till our day. Although this action cost Beuys his job at the university, both his performances and installations that aimed at connecting art and everyday praxis which he realized within the Fluxus group and his activities and manifestos within avant-garde movements have won him an unforgettable place in the 20th century art.

Although Beuys was invited to join the university some time later, the principles of the Fluxus art group within which he worked were to make contact with everyday life and with society from outside of institutions; to make life in all its manifestations the subject and context of art. This principle can be valid both for political and non-or anti-political practices. In fact, as we have seen during the GEZI events resistance and opposition have assumed reality and validity through multiple relationships, through everyday activities, practices and through art and have also attained an aesthetic content as engaging activities. The fact that resistance activities have brought together diverse people and created a social dialogue, have evolved a positive social dynamism against the separating, isolating and alienating political and 
economic systems. A resistance that is not separated from everyday practice and the awareness of the complexity of the inhabited environment can be the most effective weapon against the homogenizing and controlling strategies of administrative powers. Because diversity and complexity cannot be forced into a unified order; they constantly change center thus defeating centralized power which strives to dominate.

In this essay I will try to analyze the social structure of the city and elaborate on the political, cultural-aesthetic and ethical potential of social activities. In this respect the power of social activities to transform urban space and to create aesthetic and ethical situations will be discussed in the light of the GEZI events that took place in Istanbul in spring 2013. By applying Beuys' concept of 'Social Sculpture' to the city, the city, architecture, cultural and artistic relations will be analyzed and it will be attempted to develop the new visions for the actual political and social paradoxes.

\section{THE CONCEPT OF SOCIAL SCULPTURE}

Literature concerned with the social form and the political qualities of the city since the 1960's has largely been inspired by public manifestations of different world cities. In this context, there can be several explanations of Beuys' and his students' action which can be interpreted as social sculpture. To sweep the streets and to see the trash as socially given, points to important relations between the city and its users. Primarily, to transform the street, to give it form and to intervene are ways of claiming the city which no urban project envisages for city dwellers. Lefebvre claims that all urban projects and planning are realized in spite of the users and passify the people. ${ }^{1}$ The fact that the citizen goes out to sweep the street is a demonstration of his active involvement.

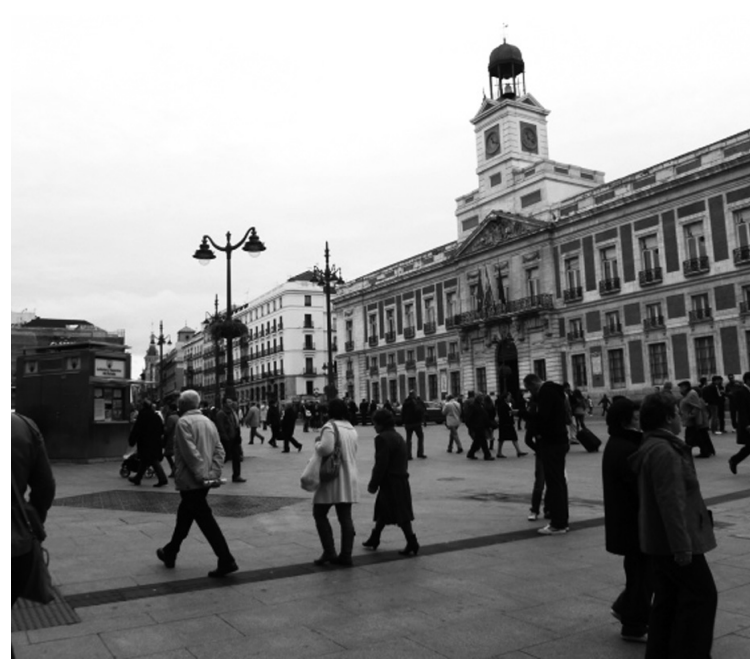

Figure 1. Madrid City Center

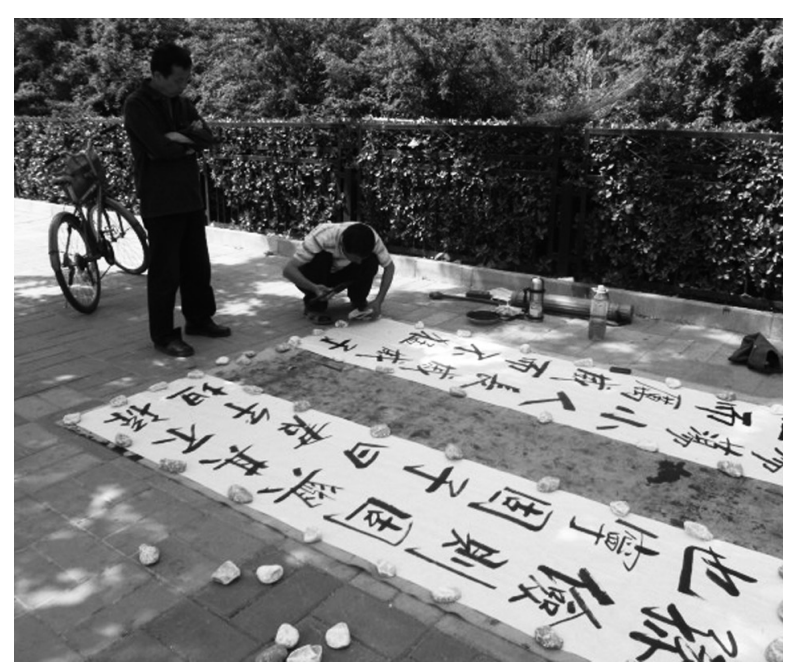

Figure 2. A street artist in Beijing 
This being the expression of a powerful will is also a transforming action. For Beuys the most important property of art was its power to change and to transform the world.

A revolution that takes place within a new social unity where everyone is creative and where creative potential of each person can be realized, for Beuys, would be a real work of art and would change the world. For him the process that creates a sculpture and the concept of sculpture can be examples of the process that can produce the idea and the shape of a revolution. Because, a sculpture is first imagined, begins to emerge as idea and thought, takes on a more definite form in time, begins to be molded and sculpted and after a definite time process reaches its final shape. A social action, in the same way, takes on shape just like a sculpture, through a process. Therefore, Beuys sees sculpture as the symbol of a social action. Social Sculpture means for him how we realize, how we shape and transform the world in which we live. ${ }^{2}$ The increasing social uprisings of our day, in the words of Beuys, are 'the art of action' and may be pointing to the evolution of a public art which Beuys prophesized.

Today, in the light of these manifestations, we have begun to understand, to question, to interpret and to conceive in their multiple potentials cities, public urban spaces, green areas, streets, pavements, walls and areas that are accessible or closed to the citizen. In fact, the action of Beuys and of his students and later the uprisings against urban conditions by the youth and by the people who are excluded, have to be seen as active participation in the city. In other words, this means to be part of the physicality of the city with one's own body. This kind of participation inevitably becomes both a material and a spiritual content of the city. When people actively get involved in the urban environment, physically, through taking active part, they become not only the content, but also the context, because it is their drive which creates the greater meaning of the urban field. The images from the Gezi event have shown that the basic structure of the city is its social body.

In this respect it would also be helpful to try to understand vandalism and aggressive actions by the young people of peripheral settlements, such as the ones that took place outside Paris in 2010, as a way to be part of urban reality, in a negative way, because the venues of positive action were not possible nor were they indicated to the youth.

I would like here to step aside and mention the actions that destroy or litter public sculptures in parks and public areas. Many of these cannot be called 
vandalism because they do not intend to destroy (even if in the end they have a negative effect) but rather to be part of the work and to be visible in the city. Many young men sign their names and put up signs indicating their romantic interests, or stick their portraits or logo's onto the sculptures. Such action is a demonstration that these people also want to take part in shaping the city and to express themselves, very much like most of graffiti, some of which is considered today as public art. To turn this into a positive act is possible, by allowing and making it possible in educative and material ways, the positive action by these people.

Negative acts that can be called vandalism are also rooted in the impossibility felt by some people in participating in the shaping of the environment and in feeling excluded. This is an issue that has to be treated separately. None of the political demonstrations, such as the Gezi or Seattle events can be seen under this category. On the contrary they were always peaceful and often aesthetic in several ways.

\section{URBAN STRUCTURE}

Today the reality of the city no longer resides in its static physicality, in its buildings, streets, avenues, but in the social dynamics, in the life rhythm of its people, in the communication networks. Many of the static buildings in a city can be seen as places where people are isolated and cut off; the real city, the city where time and space are dynamic is the geography where people are interacting, where relationships are possible and where spaces become alive with the actions of the people. This geography may sometimes become invisible, but is transformed into a network of communication and transmission; it becomes a field of awareness and affect.

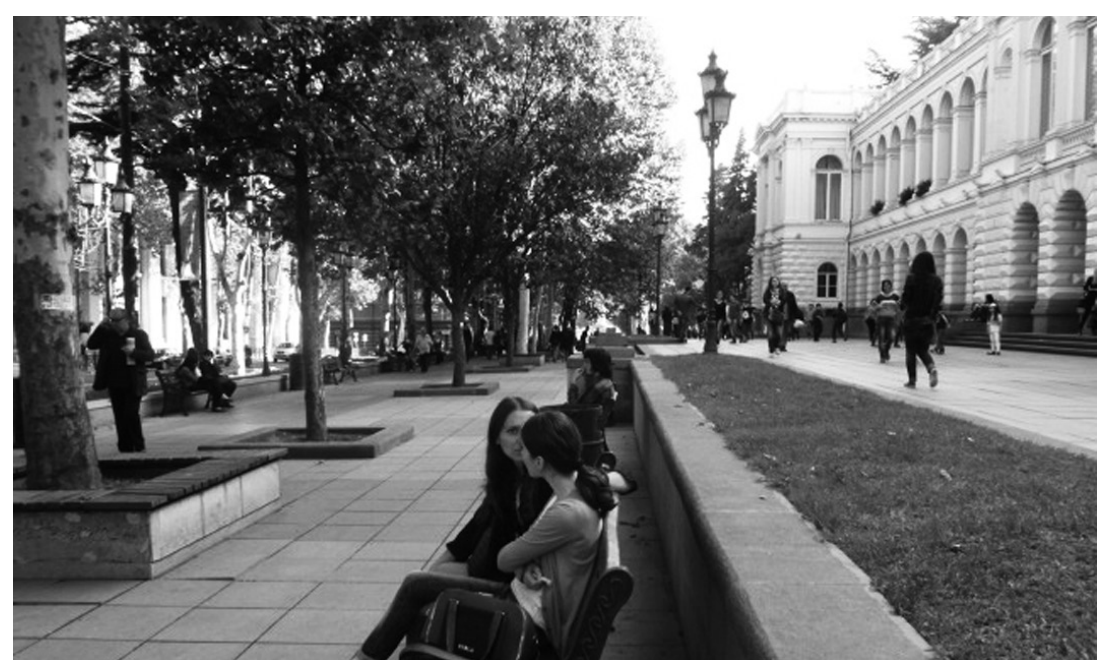

Figure 3. Sidewalks in Tbilisi 
Today the city is perceived in a different manner and is represented by different kinds of maps. Social media, the information networks created by the public, by individuals, create an effective and dynamic field underneath the physical structure of the city. This interactive dynamics which is carried on today mainly through social media creates an invisible but forceful atmosphere and almost a metaphysical power. In a way it is seen and felt in the behavior, attitudes and expressions of the people. It is a kind of energy which permeates everything. This creates a new urban map which enables us to see the city in a new light. Besides, it is the active and the atmospheric presence of the living, of human bodies, of social movements and of kinetic dynamism that totally transform the image and the concept of the city.

Thinking of the city in conventional ways brings to our mind the architectural and physical matter, the streets, buildings, walls, fences, boulevards, shop windows, buildings erected in a static manner and asphalted roads. Like a huge model. A static structure. And a wall that hinders human movement. The city of Tokyo which Wim Wenders photographed while everybody was sleeping looked like a ghost town. We usually think of cities in this way. Even if there are people they move between these structures as mysterious shadows. Each new era creates different forms in this configuration. Buildings rise up and are torn down, then get replaced by new ones which create new appearances; but each time we look and imagine the city, we think about it as the mixture of static forms.

In this connection the fact that we have to perceive both the urban structure and its architecture in new ways has become obvious with the recent uprisings. What is crucial is not to design and to build the city with buildings. A new awareness has emerged in which it is important to evaluate the complexity of

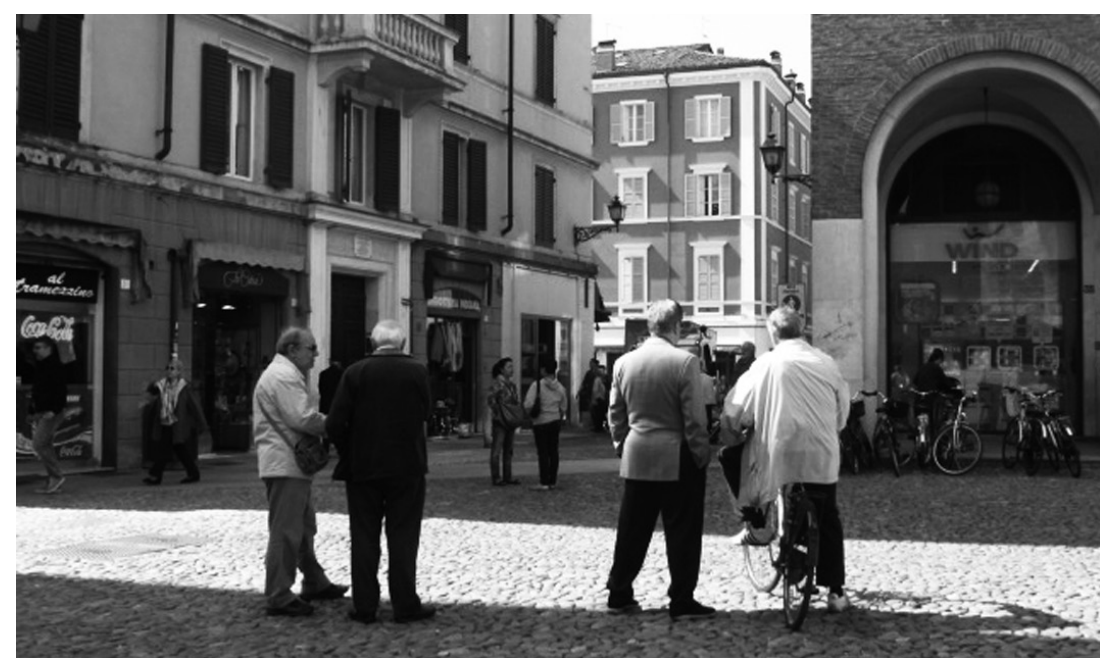


the lived spaces as a pool of knowledge and to evaluate the complexity also as an occasion for engagement. In this relation, the centers and peripheral areas of cities, the areas beyond control can enable us to perceive the urban reality as a new geography. In fact, as we understand after the Gezi events or from the uprisings in the Paris suburbs in 2010, it is impossible to design or to build the city as a social space with the conventional design concepts and with reactionary political solutions. Up till today, all academic or municipal projects have regarded urban problems from the point of view of traffic, housing or shopping, usually catering to market economy. Research on how sponsors engage in such projects have shown that sponsors do not consider any social analysis for such projects as beneficial or necessary and that they usually use the income to their own ends. ${ }^{3}$

\section{SOCIAL STRUCTURE}

The city, with its structure and dynamics is totally a political field. It is because every kind of urban space is a field of struggle between ownership, participation, economic and power relations. As mentioned previously, human relations, production, the market, consumption and thus power relations make up the real structure and the vital mechanism beneath the physical matter. The physical structure of the city, its architecture and circulation network and its relation with nature can only be understood in relation to these forces. In general, the interventions and planning in cities are conditioned according to the actual paradigms; i.e. when motorized traffic and the sale of vehicles become an important aspect of the economy, the design of roads becomes a priority. Thus, the urban structure of different eras always reflects the social structure and the life style of a certain era.

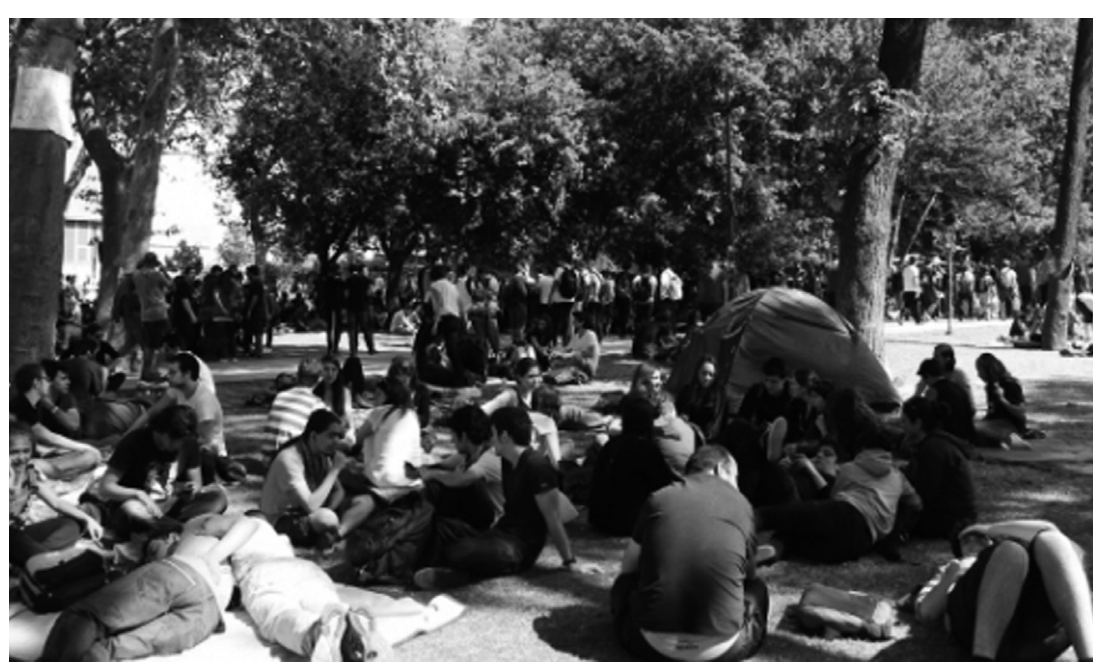

Figure 5. People claiming Gezi Park. Source: www.guncelliyorum.com 
Since even before the industrial era, the 'commons', spaces and land that belonged to people who lived there have constantly been expropriated to render more income to the holders of power. Marx, in the Capital writes about the English peasants who were thrown out of their land and who had to find new kind of work to survive until this work also proved lucrative enough to have them evicted also from this new place of work. ${ }^{4}$ As J. Claramonte has shown in his book "La Republica de Los Fines" the story of the American West, the Eldorado, where the former immigrants from Europe settled to make a living also becomes a place of struggle where the powerful finally throw out all pretenders. ${ }^{5}$ The story of Western movies is continued in the Asphalt Jungle of New York and Chicago where now those who seek for survival have to find clandestine means.

The regular privatization by power and authorities of spaces, which have been used by the people for different purposes since the fifteenth century, and which can be called 'commons', has today become one of the most striking issues of unrest in cities. ${ }^{6}$ The struggle between the public and the state, which is represented by police forces, is shown by the state and state authorities as aiming at a defense and protection of public space. The aggressive occupation and prevention of access to such spaces by state authorities are realized most of the time by using violent and inhuman means such as teargas and plastic bullets which do not only target demonstrators, but affect whole neighborhoods and people who are not involved. Such aggressive measures are not only responses to the demonstrators, but imply a threat against all opposition.

The many uprisings that have taken place in the recent years have shown that the city has to be perceived with new paradigms and values. The role of social

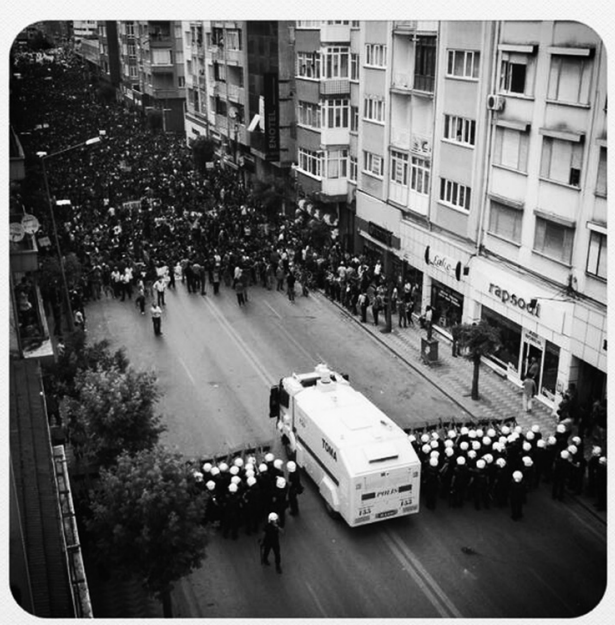

Figure 6. Source: occupygezipics

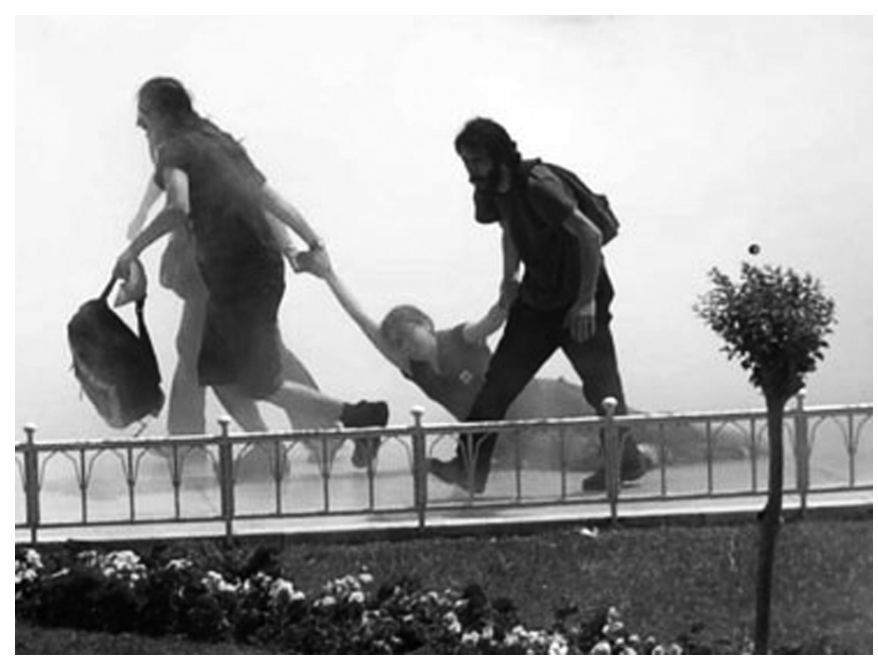

Figure 7. Source: occupygezipics 
habits is also crucial in the way the public assumes its rights to the city and in the way a city can become a social architecture or a social sculpture. In general, in Eastern or Muslim cities areas outside the home or outside of a housing complex (as in China) are not the responsibility of the people. People do not assume any right over urban areas which are under the monopoly of the administrative forces. This politics which has been effective for centuries has blinded people's sensibilities towards the environment. In Turkey until recently very few people have written on urban conditions or have voiced opposition against state policies. However, today Gezi events show that the new generations perceive the city differently and that they are aware of the political, social and aesthetic potential of cities. With the Gezi events, two important urban concepts have surfaced: the first is that open areas are social property and do not belong to administrations, the second is that parks are vital socially, aesthetically and ecologically.

As Uğur Tanyeli has articulated in detail in his text in the İstanbul Biennial's 2005 Book of Texts, the Ottomans did not have concepts or linguistic and practical differentiation between public and private areas. ${ }^{7}$ The spatial concepts that have been differentiated by definite boundaries in the English are interwoven in the Ottoman culture and have not been produced as separate words. Today, places known as 'public' are understood as being open to public services always under state control and are never open to the free use of the public. Uğur Tanyeli's reference in the same article to Walter Benjamin's Flaneur, in other words to the person who roams the city freely and who interprets urban images has never been valid for Turkey. The person whom Walter Benjamin calls 'Flaneur' and who gives meaning to spaces socializing them through his/her subjectivity as s/he enters the labyrinth of the city is the person who has realized and internalized the modernization of the Western

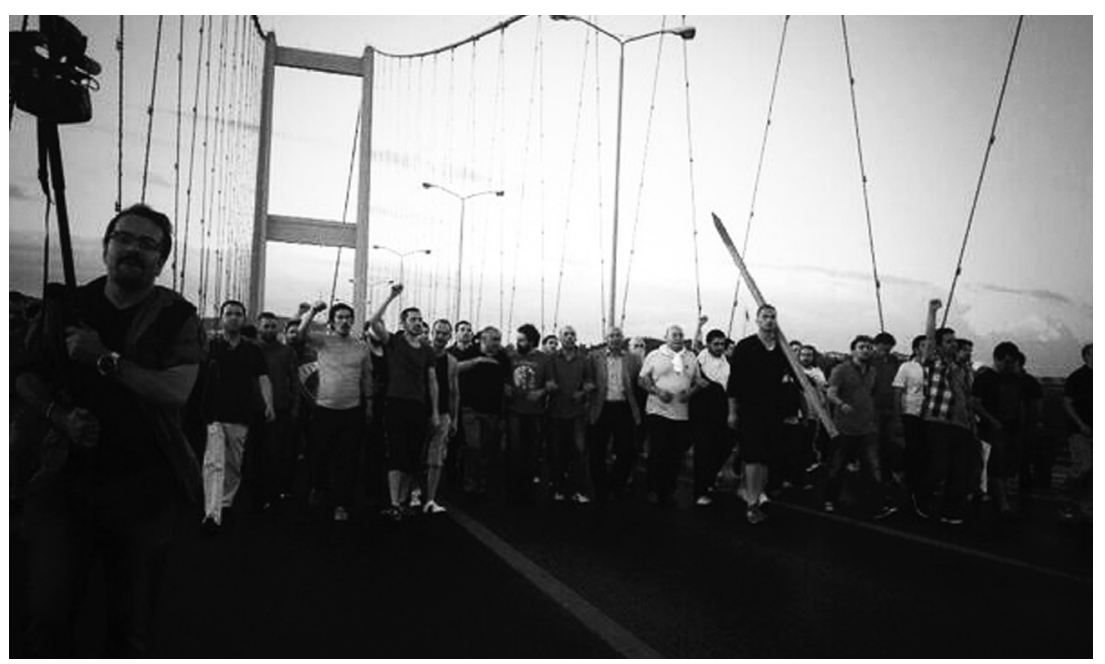

Figure 8. Source: occupygezipics 
city. It is difficult to understand the modern Western city without it, because now the city is not a place where man fulfills his functions from a static position, but is a subjective field that is created over and over again through new discoveries, through walking and through attributing new meanings to it. This circulation which will increasingly become motorized, is still today possible to be walked and roamed about without an aim. In Turkey, however, as Tanyeli emphasizes, walking is only an activity done to go from one place to another, to the degree allowed by the speed of the traffic. This proves that the social and private means developed by modern cities for individuals have not yet appeared within the Turkish culture. The different manifestations and uprisings that have surfaced in parallel to the Gezi events have shown that the urban reality of the Turkish cities is being questioned today.

\section{ISTANBUL THE OPEN CITY}

It would not be wrong to make a generic interpretation of why uprisings and social events in Turkey started in Istanbul. These activities have made us reconsider the concepts of boundaries, of the other, of ourselves, of the stranger, the alien and the local. In 1997 at a conference that was organized with the participation of Jacques Derrida, İstanbul was defined as a city which brought together the above mentioned aspects and the concept of the city was analyzed from the positions of inside, outside, boundary and passage. "Istanbul appears as a city the foundations of which are constantly changing and which constructs itself anew with each destruction. Therefore, from metaphysical and conceptual perspectives this city constantly challenges the conventional logic which is based on obvious contrasts and harmony. Istanbul is the living representation of aporia (the contradictory and the unsoluble) - (meaning barriers, porosimpossibility of passage); here, the same and the different, various peoples and cultures are neighbors in their localities and in foreign territories. ${ }^{8}$

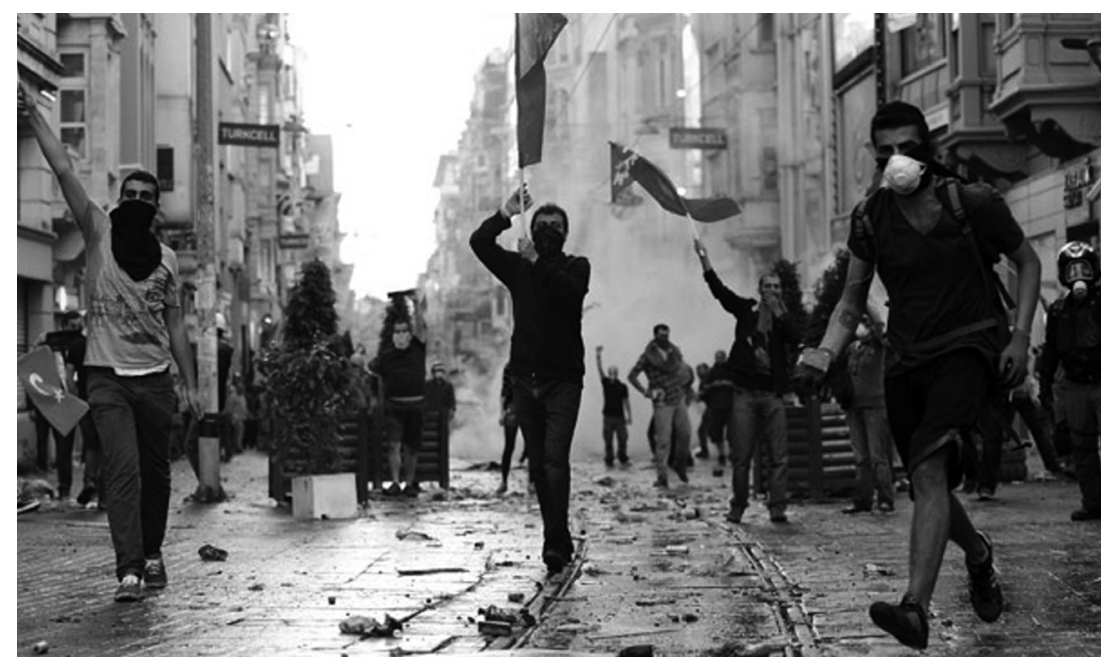

Figure 9. Beyoglu during Gezi Protest. Source: occupygezipics 
Although Istanbul symbolized the concepts of boundary and passage with its geographical and historical qualities, the dynamics of globalization has created similarities amongst all world cities, with migrations, customs, commerce and terror. From this point of view the urban environment becomes an area of social and spatial struggle where prohibitions and liberties are in constant conflict and where boundaries constantly change. Structures that are not static, such as social movements, may upset and change the order of the city and may create small but independent institutions. As has been seen in the recent social movements, in contrast to the high income groups and administrative institutions that play a crucial role in the shaping and control of cities, the fact that peripheral groups have been able to assume rights over urban spaces have created unexpected transformations and have changed the image and structure of the city. For example, the 'standing' action that was realized after the GEZI events, has created complex images and orders that can be interpreted in many different ways. In this way, a new questioning of urban spaces has become possible. Even with short intervals different spaces in a city can assume a close relationship, thus affecting each other. Spaces are influenced by power and repression, but what influences them most are boundaries and the way boundaries enter and oppose the center.

\section{PLANNING AND SHAPING}

How can we, from the perspective of the above questions and analyses, evaluate the dilemma in which the urban planners, landscape architects and architects who have a role in the physical formation of the city, find themselves? Till today in all urban constructions it has been attempted to solve the functional and aesthetic requirements of cities through static structures and orders. For example, the sculptures and decorative objects which are used to make a city more appealing have often been conceived as objects that offer single and dogmatic meanings. The aesthetic research shows that designs which most affect and engage people are those which are open to various interpretations and which have complex attributes. Rather than a static monument, objects which offer colors, movement and various meanings and which address various senses please people more readily. Therefore, situations which have not lost their natural qualities of light, sound, movement, liquidity and environments where people can physically be free and unrestrained are more attractive than the areas where there is not a single dried leaf and which have monuments and a static order. We can understand why the GEZI events were important for several reasons. First of all to assume the right over the park was crucial. One cannot underestimate the importance of this for the city of Istanbul where green areas are insufficient in proportion to the population. But, beyond this the activities in GEZI Park, the tents, the coming together of people from 
different age groups and classes has created a new aesthetic atmosphere and has played an important role in people's participation in the uprisings. People as the youth, as the aged, men, women with their different looks and gestures, with their posters, tents, songs and most important with their bodies which are more meaningful than any object, have turned the urban space into an aesthetic field, into a performance, a social artwork and into a social sculpture. With the multiple qualities of human beings and with the multiple meanings of bodily movements the political was transformed into the artistic. The fact that contemporary art today is related to the political is based not so much on the engaging and awakening potential of art but on the fact that social phenomenon contains aesthetic qualities more than anything else and that it is symbolic and sensually stimulating. When art is directed to social phenomenon a concrete aesthetic which creates sensory participation becomes possible. Social and political events and claims can be more profoundly internalized when they use the engaging formal potential of art.

On the other hand, images even when they are not intended as art, when they are merely documents, do also relate us to other people, to other situations and place us in another context. Thus they can be effective tools in creating social consciousness and a political engagement. Digital imagery, because it can be shared on such a large scale has a great engaging power, as we have witnessed in the spreading of political uprisings of the last several years. The image engages us personally both as a symbol that appears within our own private mental space and as something that connects us to the world. Through the images of the uprisings that have been diffused widely we came to identify with the actors and to engage in a common cause.

\section{A NEW CULTURAL ALTERNATIVE}

A cultural realm which is not imposed from above but which develops through sharing and participation is possible only with the free use of the city and the interaction of different groups, of different people, of workers and of artists. This in turn will create the ethical spaces and material forms of the city. Architecture which is aesthetic and which serves people, in other words places which will render people happy and free upon their use, places where people can be neighbors can only be constructed through such social means. The real culture and the democratic condition can be created today with the interaction and proximity of different people. Today, whether it is music, sculpture, architecture, urban planning or contemporary art, culture and cultural phenomena will be the product of new sensibilities, values and desires created by diversity. We can see that contemporary art develops in this direction. But it is also this plural and diverse cultural environment which has to form 
architecture and city planning that has to be ethical and valid for communal good. The physical structures of the desired democratic environment will only be able to rise up in such a democratic environment to oppose the structures that serve the high income groups which have been created by repressions and dealings of corporations and power structures.

To think of the city entirely as a social dynamics points to a new humane awareness and holds the belief that both architecture and design and urban planning can assume reality by the forms of social content. From this point of view, the expectations regarding the future of the city should concern primarily the opening of alternative social and private-individual spaces. Architecture, planning, and construction of the city should not be in the monopoly of those who hold the economic power and production tools but should belong to alternative institutions that are being newly formed. The possibility of creating new open spaces depends on new humane designs that take into consideration the needs of individuals and of the community. New alternative spaces cannot be constructed by decisions imposed from above, but by social movements where people can make themselves heard as individuals in a community and express themselves both with their physicality and their composure. The city can be an ethical place not through its shape but through its content. The city has to be a place where difference and plurality can exist without being separated and homogenized. As the conference brochure of the French Institute of Anatolian Research emphasized, only passages, pores, openings - pera peras poros -can render the city into a place where the stranger can feel at home.

\section{TOWARDS A SYNTHESIS:}

While the recent social actions that have taken place in many parts of the world point towards a new awareness of urban possibilities and rights, by way of demonstrations, their images and related art events which have been produced alongside, a new kind of artistic atmosphere and production has become implied. Although galleries and museums are still part of the urban art arena, it seems that a new form of art is slowly emerging. The diversity and pluralism that art harbors in its nature will certainly continue to allow all kinds of art forms, both conventional and contemporary; yet, I believe that the aesthetic dimension of the political actions have made people, who may not necessarily be artists, become aware of an aesthetic possibility and of their engagement and contribution to an artistic cause. Thus, the fact of people coming together in the city, for a common cause, has also opened up new possibilities for art created on a communal and social basis. It may be too early to claim this for the moment, but Beuys' dream of everyone becoming an artist, may be realized when people come together for a meaningful cause and produce a new aesthetic. 

Center, http://www.walkerart.org/archive/F/A44369B1F42E32026178.htm.3. (Berlin: Sternberg Press, 2011), 34-39.

Karl Marx, Capital, Vol. 1, Intro: Ernest Mandel, trans. Ben Fowkes (London: Pelican Books, 1976). Jordi Claramonte, La Republica de Los Fines (Region de Murcia: Coleccion Ad Hoc 29, 2011). Karl Marx, Capital,Vol. 1, Intro: Ernest Mandel, trans. Ben Fowkes (London: Pelican Books, 1976). Uğur Tanyeli, Genişleyen Dünyada Sanat, Kent ve Siyaset, (Art, City and Politics in the Expanding World - Texts from the $9^{\text {th }}$ Istanbul Biennale, ed. Deniz Ünsal (İstanbul: İstanbul Kültür Sanat Vakfi, 2005), 199-209.

Pera Peras Poros, «Jacques Derrida ile Disiplinlerarası Atölye» [«Interdisciplinary Workshop with Jacques Derrida»] (Fransız Anadolu Araştırmaları Enstitüsü, İstanbul, tanıtım broşürü, 09-10 Mayıs 1997 [The French Instıtute of Anatolian Research, İstanbul, Information Brochure, 09-10 May 1997]), translation by the author.

Claramonte, Jordi. La Republica de Los Fines. Region de Murcia: Coleccion Ad Hoc, 2011. Lefebvre, Henri. La Revolution Urbaine. Paris: Gallimard,1970.

Miessen, Markus. The Nightmare of Participation-Crossbench Praxis as a Mode of Criticality. Berlin: Sternberg Press, 2011.

Marx, Karl. Capital, Vol. 1, Intro: Ernest Mandel, Trans. Ben Fowkes. London: Pelican Books, 1976.

Tanyeli, Ugur. "Art, City and Politics in the Expanding World," in Texts from the $9^{\text {th }} \dot{I}_{\text {stanbul }}$ Biennale, ed. Deniz Ünsal. İstanbul: İstanbul Culture and Art Foundation, 2005.

Coverley, Merlin. Psychogeography. Wales: Pocket Essentials, 2006.

Harvey, David. Rebel Cities. London: Verso, 2012.

Virilio, Paul. 'La Ville Surexposée', L'Espace Critique. Paris: Christian Bourgeois, 1984.

Guattari, Felix and Antonio Negri. New Lines of Alliance - New Spaces of Liberty. Brooklyn, USA: MayFlyBooks, 2010. 


\section{GRAD KAO DRUŠTVENA SKULPTURA}

\section{Jale Erzen}

Argumenti u ovom radu pokušavaju da pokažu da je grad u osnovi društveni prostor i da su pre njegove fiksiarne materije u formi arhitekture i urbanih struktura ipak to ljudi koji izgrađuju bitan karakter i prisustvo grada. Ideja društeve skulpture je uzeta kao živopisna metafora koja se poziva na prethodni rad i ideje Jozefa Bojsa. Bojs je tvrdio da su događaji i postupci ljudi u gradu društvene skulpture i to je ilustrovao u svom čuvenom performansu čišćenja ulica sa svojim studentima. Grad pripada ljudima i gradovi su odgovornost svojih stanovnika. Zalažući se za to, ovaj rad se isto tako poziva na GEZI događaje u Istanbulu. Ovi argumenti vode do zaključka da će vitalnija i značajnija umetnost u budućnosti morati da se odnosi na urbani kontekst više nego na bilo šta drugo.

KLJUČNE REČI: DRUŠTVENA SKULPTURA, GRAD, AKTIVIZAM, DRUŠTVENO TELO, NOVA UMETNOST

\section{UMETNOST (IZ) ODVAJANJA: ESTETIKA OKO ZIDA}

\section{Zoltán Somhegyi}

Zid je neophodan arhitektonski element, koja odvaja a u isto vreme ujedinjuje, stvarajući strane, podele i mogućnost proboja. Koje estetske potencijale i kvalitete možemo da nađemo oko zida? Ponekad se skoncentrišemo više na ono što zid obuhvata, ali možemo stvarno sam zid da stavimo u fokus, na primer, prilikom ispitivanja zida u ruševnom stanju: kada čak bukvalno možemo da hodamo oko samostojećeg vajarskog predmeta, ili kada ga tumačimo kao predmet i medijum vajarskih intervencija. U ovom radu, uz pomoć nekih umetničkih dela želeo bih da ispitam ulogu, pojavnost i „korišćenje“ zida, i da pokažem neke zapažene primere gde su arhitekte i umetnici bili inspirisani da pronađu nova tumačenja ovog klasičnog arhitektonskog elementa.

KLJUČNE REČI: ZID, RUŠEVINE, PRIRODA, VAJARSKA INTERVENCIJA, SAVREMENA UMETNOST

\section{“INTERNACIONALNI" STIL ARCHITEKTURE U JAPANU TRIDESETIH GODINA: VERNAKULARNOST I MONUMENTALNOST}

\section{Daiki Amanai}

Nakon ovladavanja Zapadnom arhitekturom hiljadu devetso desetih, japanske vrhunske arhitekte su bile suočene sa dva problema: kreiranjem sopstvenog stila koji se bazira na japanskim tradicijama i klimatskim ili seizmološkim uslovima i obrazovanjem običnih ljudi da stvore ukus za arhitekturu izvan površne imitacije onog sa Zapada. Pre svega, jedan od elite i prvobitni ekspresionista arhitekta Horiguči Sutemi je diskutovao o ne-urban-nosti koja povezuje japanske čajane i holandske seoske kuće. To je izrazio putem svog modernističkog tiumačenja funkcije, svog iskustva u Holandiji i reakcijom protiv administrativnih stavova o gradu i arhitekturi iz dvadesetih godina. Drugo, uprksos svom ranijem udaljenom stanovištu o monumentalnosti, njegov zahtev za vrhunskim izražavnaje nekih projektovanih spomenika širom sveta je revitaliziralo njegovu sopstvenu sklonost. Naizgled njegovi stavovi prema monumentalnosti su se promenili i osobina spomenika koji su odavali počast žrtvama rata ili podizala nacionalni ugled bila je suprotstavljena "internacionalnoj" odlici moderne arhitekture. Iako ove poente mogu da prikriju njegovu doslednost, možemo da pronađemo njegov kontinuirani dualizam: jedno je funkcionalnost koja je prevladala nad arhitektonskim diskursom tog doba i Horiguči je isto tako smatrao a drugo je njegov izraz koji je lokalnoj vernikularnoj praksi obezbedio poziciju u svetu. Ovi argumenti nam omogućavaju da među moderne arhitekte iz tog doba ubacimo potencijalno razumevanje ali u novom svetlu. 